\title{
IMPLEMENTASI PERILAKU CARING PERAWAT PELAKSANA TERHADAP KEPUASAN PASIEN DI RUANG RAWAT INAP RUMAH SAKIT GRANDMED LUBUK PAKAM
}

\author{
Rahmad Gurusinga ${ }^{1}$, Tati Murni Karokaro ${ }^{1}$, Arfah May Syara ${ }^{1}$, Syatriawati \\ Suhaimi $^{1}$, Sari Desi Esta Ulina Sitepu ${ }^{1}$, Anita Sri Gandaria Purba ${ }^{1}$, Sarmana ${ }^{1}$ \\ ${ }^{1}$ Program Studi Keperawatan, Institut Kesehatan Medistra Lubuk Pakam \\ JIn. Sudirman No.38 Lubuk Pakam, Kabupaten Deli Serdang, \\ Sumatera Utara - Indonesia \\ *email korespondensi author: rahmadgurusinga@medistra.ac.id
}

DOI $10.35451 /$ jpk.v1i1.744

\begin{abstract}
Abstrak
Sebuah rumah sakit dikatakan berhasil dalam memberikan pelayanan kesehatan apabila di dukung oleh beberapa faktor, yang menjadi salah satu faktornya yaitu pelayanan keperawatan yang berkualitas, pelayanan keperawatan merupakantitik penentu keberhasilan rumah sakit dalam meningkatkan mutu pelayanan kesehatan untuk meningkatkan kepuasan pasien karena pasien merupakan tolok ukur dalam mutu pelayanan. Salah satu bentuk pelayanan keperawatan yang dapat diterapkan yaitu perilaku caring perawat karena perawat merupakan orang yang paling sering berinteraksi dengan pasien. Tulisan ini bertujuan untuk memberikanImplementasi Perilaku Caring Perawat Pelaksana Terhadap Kepuasan Pasien di Ruang Rawat Inap Rumah Sakit Grandmed Lubuk Pakam. Metode pelaksanaan kegiatan dengan menggunakan kuisioner yang menjadi sasaran dalam kegiatan PKM adalah Perawat pelaksana dan pasien rawat inap. Dari hasil kegiatan yang dilakukan terjadi peningkatan kepuasan pasien hingga 64,3\%. Dengan kegiatan PKM ini diharapkan dapat memperbaiki mutu pelayanan kesehatan di Rumah Sakit Grandmed dan dapat lebih meningkatkan kepuasan pasien yang berkunjung.
\end{abstract}

Kata kunci: Perilaku Caring, Perawat Pelaksana, Kepuasan Pasien

\begin{abstract}
A hospital is said to be successful in providing health services if it is supported by several factors, one of which is quality nursing services. service quality. One form of nursing service that can be applied is the caring behavior of nurses because nurses are the people who interact with patients the most. This paper aims to provide the Implementation of Caring Behavior for Implementing Nurses on Patient Satisfaction in the Inpatient Room at Grandmed Lubuk Pakam Hospital. The method of implementing activities using questionnaires that are targeted in PKM activities are implementing nurses and inpatients. From the results of the activities carried out there was an increase in patient satisfaction up to $64.3 \%$. With this PKM activity, it is hoped that it can improve the quality of health services at Grandmed Hospital and can further increase the satisfaction of visiting patients.
\end{abstract}

Keywords: Caring Behavior, Implementing Nurse, Patient Satisfaction

\section{Pendahuluan}

Suatu rumah sakit dikatakan berhasil dalam memberikan pelayanan kesehatan apabila di dukung oleh beberapa faktor, salah satunya yaitu pelayanan keperawatan yang 
Received: 15 June 2021 :: Accepted: 18 June 2021 :: Published: 30 June 2021

berkualitas. Dengan demikian pelayanan keperawatan merupakan titik penentu didalam pelayanan kesehatan di suatu rumah sakit karena dijadikan sebagai salah satu indikator mutu pelayanan kesehatan untuk meningkatkan kepuasan pasien. Selain itu, salah satu bentuk pelayanan keperawatan yang harus mendapat perhatian yaitu perilaku caring perawat yang menjadi inti atau fokus dalam keperawatan dan sebagai bentuk praktik keperawatan secara professional. (Gurusinga. R, \& Wulan.S., 2014).

Perawat harus melayani dan berperilaku caring kepada pasien, karena hal tersebut menjadi dasar pada saat memberikan perawatan kepada pasien sesuai dengan standar keperawatan. Oleh sebab itu, perilaku caring perawat perlu dikembangkan sesuai dengan kebutuhan saat ini di rumah sakit (Watson, J, 1979).

Rumah Sakit Grandmed merupakan salah satu rumah sakit paripurna atau Rumah Sakit swasta Tipe B yang terletak di Kabupaten Deli Serdang Sumatera Utara dan memiliki keunggulan termasuk didalamnya komitmen terhadap mutu pelayanan, kemudahan dalam akses, dan menerapkan pelayanan yang berkualitas tetapi masih ada juga perawat di RS Grandmed yang belum mengutamakan mutu dan kualitas pelayanan meskipun jumlahnya relative kecil, dari hasil kunjungan tim PKM di rumah sakit Grandmed, ada beberapa pasien yang ditemui di ruang rawat inap mereka menyatakan masih ada perawat yang belum cekatan dan ceroboh dalam memberikan tindakan ataupun pelayanan serta tidak memberikan senyum atau sapa pada saat masuk keruangan rawat inap mereka hanya memberikan tindakan kemudian langsung keluar, selain itu juga perawat masuk keruangan secara ramai-ramai pada saat pergantian shif, sehingga menganggu istirahat pasien.

Perawat merupakansalah satu orang yang menjadi kunci dalam memenuhi kepuasan pasien di rumah sakit (Nursalam, 2011). selain itu, Perawat juga merupakan orang yang paling dekat dengan pasien selain keluarga, sehingga

dalam melaksanakantugasnya sebagai seorang perawat harus memperhatikan perilaku caringkarena caringmerupakan upaya yang bisa dilakukan untuk memberikan pelayanan sehingga dapat memberikan kepuasan dan kesembuhan kepada pasien oleh sebab itu perlu diadakan implementasi atau penerapan Perilaku Caringperawat untuk menambah pengetahuan dan keterampilan perawat karena semakin baik perilaku caring perawat maka akan semakin tinggi pula tingkat kepuasan pasien sehingga dapat mempercepat proses penyembuhan pasien dan meningkatan mutu pelayanan rumah sakit.

\section{Metode}

Metode yang digunakan pada PKM yaitu dengan melakukan penyuluhan tentang implementasi perilaku perawat, sebelum dilakukan penyuluhan di ukur tingkat kepuasan pasien dan setelah 2 hari pasca penyuluhan diukur kembali tingkat kepuasan pasien. Media yang digunakan dalam kegiatan PKM yaitu Power Point dan video yang ditampilkan dengan menggunakan LCD dan layar proyektor, sedangkan alat ukur yang digunakan adalah Kuisioner yang berisi tentang 5 indikator perilaku caring dan 3 indikator tentang kepuasan pasien.

Kegiatan PKM dilaksanakan di Rumah Sakit Grandmed Lubuk Pakam pada bulan Maret 2021 yang menjadi sasaran dalam kegiatan ini adalah seluruh perawat pelaksana di Ruang Rawat inap Rumah Sakit Grandmed sebanyak 155 orang dan seluruh pasien rawat inap yang memenuhi kriteria inklusi dan eksklusi sebanyak 70 pasien. Analisa data diolah secara statistik, kemudian hasilnya disajikan dalam bentuk tabel distribusi frekuensi (Sugiyono, 2014).

\section{Hasil dan Pembahasan}

Implementasi perilaku caringperawat pelaksana terhadap kepuasan pasien di Rumah Sakit Grandmed Lubuk Pakam

Tabel 1. menunjukkan bahwa distribusi perilaku caring perawat pelaksana mayoritas perilaku cukup sebanyak 76 orang $(49,0 \%)$ dengan kategori 
rentang nilai 106-137 yang terdiri dari 5 faktor penilaian, sedangkan minoritas perilaku burukhanya 2 orang $(1,23 \%)$ dengan rentang nilai 42-73.

Tabel 1. Distribusi Frekuensi

Berdasarkan Perilaku Caring Perawat Pelaksana sebelum penyuluhan

\begin{tabular}{lcc}
\hline Kategori & $\mathrm{f}$ & $\%$ \\
\hline Baik & 69 & 44,6 \\
\hline Cukup & 76 & 49,0 \\
\hline Kurang & 8 & 5,17 \\
\hline Buruk & 2 & 1,23 \\
\hline & 155 & 100 \\
\hline
\end{tabular}

Tabel 2. DistribusiFrekuensi

Berdasarkan Perilaku Caring Perawat Pelaksana setelah penyuluhan

\begin{tabular}{lcc}
\hline Kategori & $\mathrm{f}$ & $\%$ \\
\hline Baik & 85 & 54,2 \\
\hline Cukup & 62 & 40,0 \\
\hline kurang & 8 & 5,17 \\
\hline Buruk & 1 & 0,63 \\
\hline & 155 & 100 \\
\hline
\end{tabular}

Tabel 2.menunjukkan bahwa distribusi perilaku caring perawat pelaksana mayoritas perilaku baik sebanyak 85 orang $(54,8 \%)$ dengan kategori rentang nilai $138-168$ yang terdiri dari 5 faktor penilaian, sedangkan minoritas perilaku buruk 1 orang $(0,63 \%)$ dengan rentang nilai 42-73.

Perilaku caring merupakan suatu tindakan yang didasari oleh kasih sayang, keterampilan, kepedulian, empati, sensitif, dukungan dan tanggung jawab. Perilaku ini digunakan untuk meningkatkan keadaan atau situasi dan kebiasaan manusiayang menekankan pada kegiatan yang sehat. Perawat harus mengetahui kebutuhan pasien. Selain itu, perawat harus membantu serta memberikan empati dan perhatian kepada semua pasien dan keluarganya. Caringdapat mewakili semua faktor-faktor yang digunakan perawat untuk memberikan pelayanan yang berkualitas kepada pasien.

Dari hasil pengmas diketahui bahwa terdapat peningkatan perilaku caring perawat pelaksana dari 44,6\% menjadi $54,2 \%$ setelah dilakukan implementasi, hal ini dikarenakan antusiasnya para perawat untuk mengikuti implementasi PKM hingga selesai dan mampu menerapkan langsung ke pasien, hasil PKM ini juga sejalan dengan teori keperawatan yang dikemukakan oleh Watson (1979), yang mengungkapkan bahwa caring merupakan suatu ciri-ciri interpersonal yang tidak dapat diturunkan melalui genetik, tetapi dapat dipelajari melalui pendidikan sebagai profesi yang ditekuni, dimana seorang perawat harus mampu dan mengetahui serta memahami tentang kebiasaan pasien dan merespon terhadap masalah kesehatan yang sudah adapada pasien atau berpotensi akan timbul masalah baru (Watson, 1999).

Tabel 3. Distribusi frekuensi Berdasarkan Kepuasan Pasien Sebelum penyuluhan

\begin{tabular}{lcc}
\hline Kategori & $\mathrm{f}$ & $\%$ \\
\hline Sangat Puas & 18 & 25,7 \\
\hline Puas & 42 & 60,0 \\
\hline Tidak Puas & 7 & 10,0 \\
\hline $\begin{array}{l}\text { Sangat Tidak } \\
\text { Puas }\end{array}$ & 3 & 4,30 \\
\hline & 70 & 100 \\
\hline
\end{tabular}

Tabel 3. menunjukkan bahwa distribusi frekuensi kepuasan pasien mayoritas pasien Puas sebanyak 42 orang $(60,0$ $\%)$ dengan kategori rentang nilai 86104 yang terdiri dari 3 faktor penilaian, sedangkan minoritas kepuasan pasiensangat tidak puas sebanyak 3 orang $(4,30 \%)$ dengan rentang nilai $26-$ 45.

Tabel 4. Distribusi frekuensi

Berdasarkan Kepuasan Pasien Setelah penyuyluhan

\begin{tabular}{lcc}
\hline Kategori & $\mathrm{f}$ & $\%$ \\
\hline Sangat Puas & 19 & 27,1 \\
\hline Puas & 45 & 64,3 \\
\hline Tidak Puas & 5 & 7,18 \\
\hline Sangat Tidak Puas & 1 & 1,42 \\
\hline & 70 & 100
\end{tabular}

Tabel 4. menunjukkan bahwa distribusi frekuensi kepuasan pasien mayoritas pasien Puas sebanyak 45 orang $(64,3 \%)$ dengan kategori rentang nilai 86-104 yang terdiri dari 3 faktor penilaian, sedangkan minoritas kepuasan pasien sangat tidak puas 1 orang $(1,42 \%)$ dengan rentang nilai 26-45.

Kepuasan pasien merupakan pelayanan kesehatan dari persepsi pasien atau keluarga yang paling dekat. 
Received: 15 June 2021 :: Accepted: 18 June 2021 :: Published: 30 June 2021

Hal ini dapat tercapai, apabila dapat diperoleh dengan hasil yang maksimal oleh setiap pasien. Pelayanan kesehatan harus mampu memperhatikan kemampuan seorang pasien baik terhadap keluhan ataupun keadaan fisik yang dihadapinya serta harus mampu memprioritaskan kebutuhan pasien, sehingga dapat tercapai kebutuhanataupun rasa puas pasien terutama didalam pelayanan kesehatan (Prompahakul, C., Nilmanat, K., \&Kongsuwan, W, 2011).

Berdasarkan hasil wawancara dengan beberapa pasien di masingmasing ruang rawat inap, sebagian pasien menyatakan ada perawat yang selalu menganjurkan pasien untuk melaksanakan terapi, mampu menjelaskan terkait dengan hasil pemeriksaan, selalu memberikan nasihat dengan tepat,tidak pernah ceroboh dalam melakukan tindakan keperawatan, selalu tenang tenang dan cekatan dalam melakukan tindakan dan selalu tepat waktu dalam memberikan tindakan serta terampil dalam melakukan tindakan.

Jika dilihat berdasarkan dimensi praktik professional sebagian besar perawat di Rumah Sakit Grandmed Lubuk Pakam telah mampu mencapai tujuan sesuai dengan peranya, hal ini dapat dibuktikan dengan hasil PKM yang diperoleh data tingkat kepuasan pasien sebelum implementasi perilkau caring perawat yang kategori sangat puas mencapai 25,7 \% dan Puas 60,0\%, sedangkan setelah implementasi perilkau caring perawat yang kategori sangat puas mencapai $27,1 \%$ dan Puas $64,3 \%$, dari hasil PKM tersebut terjadi peningkatan jumlah, meskipun masih ada beberapa perawat yang belum memberikan pelayanan yang terbaik kepada pasien tetapi jumlahnya sangat sedikit.

Pasien merupakan individu terpenting di suatu rumah sakit karena rumah sakitdijadikan sebagai bentuk tolak ukur untuk menentukan bagaimana mutu pelayanan, Pasien akan mengevaluasi pelayanan kesehatan yang diterimanya dan dapat memeberikan penilian terhadap pelayanan yang diberikan. Hasil dari proses evaluasi yang dilakukan dapat menunjukkan perasaan puas atau tidak puas terhadap pelayanan masingmasing yang diarasakan oleh pasien (Palese, A., Tomietto, M., Suhonen, R., Efstathiou, G., \& Tsangari, H, 2011).

Beberapa hal yang berkaitan dengan kepuasan atau kebutuhan seseorang relatif berbeda-beda. Seperti yang dikemukakan oleh Mc Gregor (1989) bahwa manusia adalah makhluk individu yang terus-menerus memiliki keinginan, apabila kebutuhan individu tersebutbisa terpenuhi maka kebutuhan yang lain akanmuncul (Roach, M. S, 2002). Manusia secara terus menerus akan melakukan berbagai usaha untuk memuaskan kebutuhannya masingmasing. kebutuhan tersebut dapat mempengaruhi perilaku ataupun perasaan pasien (Wolf, Z. R., Miller, Patricia, A., Devine, \&Megan, 2003).

\section{Kesimpulan}

Berdasarkan hasil PKM dapat disimpulkan bahwa hasil nilai pretest dan posttest tentang implementasi perilaku caring perawat pelaksana terhadap kepuasan pasien terdapat peningkatan jumlah pada kategorik baik, dan cukup dan terjadi menurunan jumlah pada kategorik buruk sehingga dilihat dari hasil tingkat kepuasan pasien mayoritas pasien merasa puas terhadap pelayanan yang diberikan oleh perawat hingga mencapai nilai diatas $64,3 \%$.

\section{Ucapan Terima Kasih}

Ucapan terima kasih disampaikan kepada Institut Kesehatan Medistra Lubuk Pakam dan Rumah Sakit Grandmed Lubuk Pakam, kabupaten Deli Serdang serta semua pihak yang membantu dalam kegiatan PKM ini, semoga PKM ini bermanfaat untuk semua pembaca.

\section{Daftar Pustaka}

Gurusinga. R, \& Wulan.S. (2014). Hubungan Antara Perilaku Caring Perawat Dengan Kepuasan Pasien Rawat Inap Sectio Caesaria (SC)di RS Grand Medistra Lubuk Pakam. Jurnal Kesmastra-News, Nomor 91 Volume 2 
Gadalean, I. Chepte, M., \& Constantin, I. (2011). Evaluation of patients satisfaction, Journal of Applied Medical Informatics, 29(4), 41-

Nursalam. (2011). Manajemen Keperawatan. Edisi 3. Jakarta : Salemba Medika.

Palese, A., Tomietto, M., Suhonen, R., Efstathiou, G., \& Tsangari, H. (2011). Surgical patient satisfaction as an outcome of nurses'caring behavior. Journal of Nursing Scholarship, 43(4), 341 - 350.

Prompahakul, C., Nilmanat, K., \&Kongsuwan, W. (2011). Nurses' caring behavior for dying patients in southern Thailand. Nurse Media Jounal of Nursing,1(2), 147-158.

Roach, M. S. (2002). Caring the human mode of being: A blueprint for the health professionals (2nd ed.). Canada: CH Press.

Sugiyono. (2014). Metode Penelitian Pendidikan. Bandung; Alfabeta.

Watson, J. (1999). Nursing human science and human care: Atheory of nursing. New York:National League for Nursing.

Watson, J. (1979). The Philosophy and Science of Caring. Boston: Little Brown

Wolf, Z. R., Miller, Patricia, A., Devine,\& Megan. (2003). Relationship between nurse caring and patient satisfaction in Patients Undergoing Invasive Cardiac Procedures.Medical-Surgical Nursing, 12(6), 391 - 396. 